\title{
Drivers of Transformations in Smallholder Indigenous Vegetable Value Chains in Western Kenya: Evolution of Contract Farming
}

\author{
Joseph Alulu \\ University of Nairobi \\ David Jakinda Otieno \\ University of Nairobi \\ Willis Oluoch-Kosura \\ University of Nairobi \\ Ochieng' Justus \\ World Vegetable Centre
}

\begin{abstract}
Horticultural farmers, especially vegetable producers are characterized by poor access to inputs such as credit and operate in unreliable inputs and outputs markets. Empirical evidence shows that contract farming can potentially solve these constraints. However, contract violation is evident among smallholder farmers in many developing countries. This study assessed the main drivers of recent transformations in AIVs value chains including the emerging forms of and drivers of contract violation among smallholder farmers in Western Kenya. Results from analysis of data from a focused group discussion and key informant interviews showed that climate change and technology are among the key drivers.
\end{abstract}

Keywords: contract farming, AIVs, smallholder farmers, Kenya

\section{INTRODUCTION}

The horticulture sub-sector is important to Kenya's economy due to its contribution of about $40 \%$ to agricultural Gross Domestic Product (GDP). Vegetables contribute 36\% of the total value of horticulture (Republic of Kenya, 2016). Vegetable farmers, however, face various challenges in production and marketing. These include high production cost due to high input costs, low prices for outputs, unstable markets for inputs and outputs, inadequate infrastructure, poor market information due to high transaction costs, limited access to financial services and a poor institutional environment characterized by inefficient property rights and weak market regulation (Ngeno et al., 2019). It is estimated that $60 \%$ of rural households depend on African indigenous vegetables (AIVs) for food and income. Farmers however still face challenges in accessing high-value markets (Muhanji, 2011). Indeed, Jalang'o et al. (2018) found that only less than $13 \%$ of AIVs in Western Kenya is sold by smallholder farmers in institutional high-value 
markets such as schools, hotels and hospitals due to strict requirements on quality and quantity of output, besides delayed payments.

Participating in horticultural inclusive value chains can provide an important link between the rural farmers and the global economy where local suppliers interact with global institutional buyers in trading fresh produce for instance, fruits and vegetables (Byerlee et al., 2009). African indigenous vegetables are rich in vitamins and minerals, hence important components for a nutritionally diversified diet (Ochieng et al., 2016). Such vegetables have shorter growing cycles as compared to other major crops like maize and they are able to make maximum utilization of soil nutrients and scarce water supplies (Weinberger and Lumpkin, 2007). Empirical evidence reveals that AIVs give smallholder farmers higher returns per unit area as compared to other crops like maize (Afari-Sefa et al., 2015). Some AIVs for instance, the spider plants are also known for their ease of cooking, production and processing (Kansiime et al., 2016). The AIVs also have medicinal value and are highly nutritious (Ngenoh et al., 2019). In Kenya, the area under AIVs is 45,099 ha with a total volume of 224,751 MT worth USD56,215,149 (Republic of Kenya, 2016).

In Bungoma County, spider plant is grown under 358 ha and spider plant 164 ha Agricultural activities account for about $60 \%$ of all the economic activities contributing to gross county product in Bungoma County, of which vegetables contribute about 30\%. The average poverty index in Bungoma County is $53 \%$ as compared to $46 \%$ national index, with malnutrition at about $43 \%$ (Republic of Kenya, 2019). From previous literature, it is evident that farmers in Bungoma County are vulnerable to food insecurity due to their low farm productivity. This is attributed to poor access to credit, poor infrastructure, high inputs costs and climate change (Republic of Kenya, 2019). Most farmers in Bungoma County are thus resource-poor with lack of access to reliable markets just like other farmers in most parts of SSA.

Contract farming has been viewed as the best way to overcome the constraints brought about by market failure. It is a platform that forms an institutional environment, which facilitates the integration of primary producer's into agro-industry (Prowse, 2012). As noted by Oya (2011), contract farming reduces price risk and ensures stable demand. Contract farming is an agreement between farmers and buyers. Contract farming require farmers' obligation to produce and supply products as specified in terms of quality, quantities and time. On the other hand, the buyers are obliged to facilitate upfront delivery of inputs and other non-financial services such as extension, training, transport and securing markets for farmers' produce while paying an agreed price (Prowse, 2012).

There are several determinants of smallholder farmers' participation in contract farming. Key among these include: the need to access inputs and services which cannot be obtained from the spot (traditional) markets because of lack of adequate capacities to invest in these inputs, the need to reach markets that are more remunerative and a price premium which serves as an important component of contractual package due to its impact of farmers' income (Ton et al., 2017). The World Bank (2008) and Da Silva and Rankin (2013) found that smallholder farmers are motivated to participate in contract farming in order to connect to output markets, gain access to credit and extension services. Several studies for instance; Bellemare (2012), Sokchea and Culas (2015), Bellemare and Novak (2017), show that contract farming is beneficial to the smallholder farmers by enabling them to gain better access to ready markets, both local and global thus enhancing farmers' income and contributing to better livelihoods in the long run. According to Bellemare (2015), contract farmers benefit from high and steady incomes due to increased productivity and training on good agricultural practices. The farmers receive quality recommended inputs on credit and technical skills and guidance from the contractor hence, improving yield and quality thus improving contract households' incomes.

However, contract farming is threatened by frequent breaches characterized by smallholder farmers engaging in side selling. Smallholder farmers violate contracts in cases where buyers (firms) portray unfavorable behavior for instance, when buyers provide poor extension services, offer low prices for produce, overprice their services, unfairly pass their risks to producers, and use faulty weighing scales. Other cases include; delay in payments for produce, display dishonesty by disappearing without a trace with farmers' produce before paying, favor larger farmers/exploit smallholders, fail to provide compensation for unavoidable losses and fail to explain the pricing methods used. This leads to loss of 
trust and friction in the previously established relationship between the contracting parties. Farmers who violate contracts also end up facing uncertainties in income due to unstable markets in subsequent cropping seasons (Singh, 2002).

Considering the high poverty index in the County, high malnutrition levels, low production and productivity levels among vegetable producers in Bungoma County, this study analyzed changes that have taken place across the years from 1980 to 2019, as far as input supply, production, assembling, distribution, marketing and consumption of vegetables are concerned. This study also assessed the evolution of contract farming among vegetable farmers and the major factors leading to violation of contracts among the vegetable farmers despite their perceived benefits to contribute to informed policy development.

\section{MATERIALS AND METHODS}

A multi-stage sampling approach was used whereby two sub-counties, Bumula and Kanduyi were purposively selected in Bungoma County due to their agricultural potential and significant practice of contract farming in vegetables. Four smaller administrative units (villages) were randomly selected from each sub-county and a vegetable producer on contract chosen from each village from a farmers' list provided by the local extension officers. A total of 15 stakeholders took part in the consultations and focus group discussion.

The study employed a combination of participatory approaches: consultations with input suppliers, agricultural extension officers, value addition experts and the local administrators to obtain insights on evolution of contracts and other production techniques over the years. The study also used a focus group discussion to capture trends in challenges, opportunities and their drivers along the vegetable value chain. The stakeholders involved in the focus group discussion included; input suppliers, producers of vegetables, private and government extension officers, brokers, laborers, vegetables assemblers, distributers of vegetables, value addition experts, local administrators, marketers of vegetables and vegetable consumers. Focus group discussion enhances a broader perspective of the research issues and eliminates individual bias in data collection (Milena et al., 2018).

\section{RESULTS AND DISCUSSIONS}

\section{Changes and Drivers Along the Vegetable Value Chain}

Insights from the consultations with experts and the focus group discussion reveal that there have been several changes along the traditional vegetables (cowpeas, black nightshade and spider plant) value chains in the last four decades (Table 1). From 1980 to 1990, farmers were producing traditional varieties of vegetables, for example, cowpeas, black nightshade, spider plant, and pigweed. The farmers were using organic manure, farmyard and compost manure from crop residues for vegetable production.

Farmers heavily relied on seeds that were prepared at home and preserved traditionally by smoke at the fireplace to protect them from pest infestation. There were no hybrid vegetable seeds hence farmers could preserve seeds from farm and recycle in the subsequent season. These findings are similar to those of Wainaina et al. (2016) who noted low adoption of vegetable hybrid seeds compared to maize hybrid seeds in Bungoma. There was minimal use of chemical fertilizers.

In production of vegetables during this period, it was reported that the climate was reliable. The rains were predictable and farmers could know when to prepare land and when to plant. The first rains could fall in February. There was minimum mechanization where ox-drawn ploughs and hoes were used during cultivation. Land preparation could be done in December in preparation for planting. The soils were not hard since the land meant for production was preserved and animals were not allowed to graze there. There was a low population in the area therefore less pressure on land thus there were big parcels of farming land with no fragmentation. In terms of farming credit, merry-go-rounds were used to raise funds for communal members. Farmers were producing vegetables for subsistence purposes on small scale mostly. Broadcasting method was used during planting and not line planting. These findings are in line 
with those of Chianu et al. (2008) who observed that, farmers relied much on organic manure because it was readily available. In addition, the climate was predictable and there were two major cropping seasons in a year.

During this period, droughts were not common. There were very few cases of vegetable diseases and pests infestation. There were enough seeds hence no lending. Labor was manual, offered by family members, communal laborers who only needed food or beer after supplying their farm labor in weeding, ploughing and even harvesting. There were no public extension services. This observation is consistent with Chianu et al. (2008) who found that the family members as dictated by the household head, spouse or elder siblings were offering labor.

It was revealed that, vegetable distribution was a responsibility left for the women. Women used to carry vegetables on their heads to the market places. Vegetables were packed in sacks and baskets. At the distribution stage, there were high losses recorded due to poor facilities like packaging materials, hence most vegetables could be destroyed in the hot sun. There were no good feeder roads to facilitate other effective ways of distributing vegetables. Men came in at the distribution level of the value-chain. Men were using bicycles to transport vegetable from farms to markets and from markets to markets as well. Still there were some reasonable losses incurred during transportation due to mishandling and harsh conditions like the hot sun and high temperature.

TABLE 1

KEY TRENDS AND DRIVERS ALONG VEGETABLE VALUE CHAINS FROM 1980 TO 2019

\begin{tabular}{|c|c|c|c|c|}
\hline & $1980-1990$ & $1991-2000$ & $2001-2010$ & $2011-2019$ \\
\hline 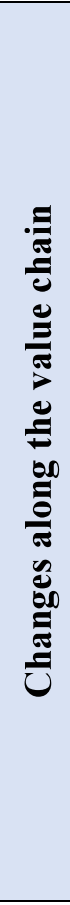 & $\begin{array}{l}\text { - Use of } \\
\text { organic } \\
\text { fertilizers } \\
\text { - Low uptake } \\
\text { of improved } \\
\text { seed varieties } \\
\text { - Bicycles used } \\
\text { to distribute } \\
\text { vegetables } \\
\text { - Low } \\
\text { assembling } \\
\text { activities } \\
\text { - low demand } \\
\text { for vegetables }\end{array}$ & $\begin{array}{ll}\text { - } & \text { Shift from } \\
\text { traditional } \\
\text { planting method } \\
\text { (broadcasting) } \\
\text { to line planting } \\
\text { - } \quad \begin{array}{l}\text { Introduction of } \\
\text { irrigation }\end{array} \\
\text { - } \text { Introduction of } \\
\text { group } \\
\text { assembling } \\
\text { Emergence of } \\
\text { supermarkets } \\
\text { Emergence of } \\
\text { motorcycles }\end{array}$ & $\begin{array}{ll}\text { - Upgrading } \\
\text { from bicycles } \\
\text { to motorcycles } \\
\text { and vehicular } \\
\text { transportation } \\
\text { - } \begin{array}{l}\text { Group } \\
\text { distribution }\end{array} \\
\text { - Increased use } \\
\text { of chemical } \\
\text { fertilizers } \\
\text { - Use of } \\
\text { improved seed } \\
\text { varieties } \\
\text { - Increased men } \\
\text { participation } \\
\text { The rise of } \\
\text { contract } \\
\text { farming } \\
\text { Digital } \\
\text { marketing }\end{array}$ & 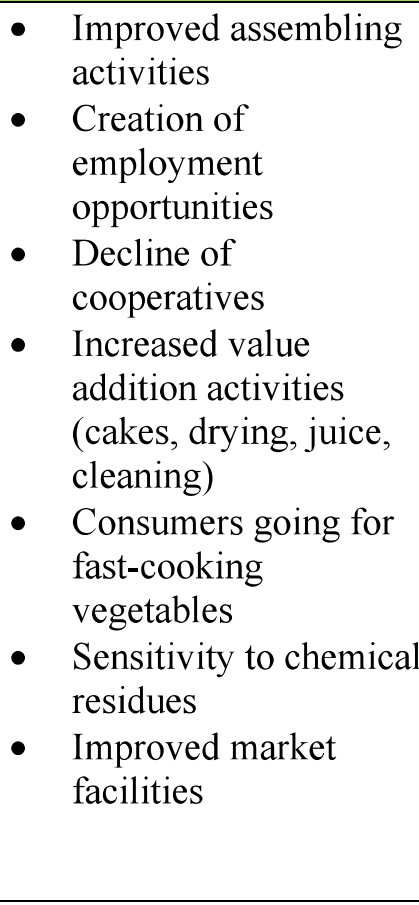 \\
\hline
\end{tabular}




\begin{tabular}{|c|c|c|c|c|}
\hline & $1980-1990$ & $1991-2000$ & $2001-2010$ & $2011-2019$ \\
\hline 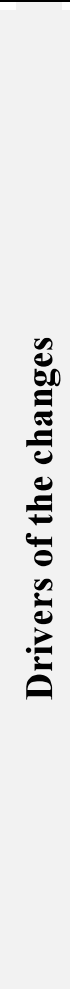 & $\begin{array}{ll}\text { - } & \text { High soil } \\
& \text { fertility } \\
\text { - } & \text { Trust } \\
\text { - } & \text { Large } \\
\text { livestock } \\
\text { herds } \\
\text { - Low climate } \\
\text { variability }\end{array}$ & $\begin{array}{ll}\text { - } & \text { Increased } \\
\text { extension } \\
\text { services } \\
\text { - } & \text { Climate change } \\
\text { - } & \text { Need for stable } \\
\text { markets } \\
\text { - Perceived } \\
\text { benefits of } \\
\text { contract farming } \\
\text { - Increased } \\
\text { demand } \\
\text { The desire to } \\
\text { maximize } \\
\text { profits } \\
\text { Increased } \\
\text { prevalence of } \\
\text { pest and } \\
\text { diseases } \\
\text { Reduced } \\
\text { livestock herds } \\
\text { and income } \\
\text { from livestock }\end{array}$ & $\begin{array}{ll}\text { - Infrastructure } \\
\text { development } \\
\text { - Increase in } \\
\text { losses during } \\
\text { distribution } \\
\text { - Loss of soil } \\
\text { fertility } \\
\text { - Increased } \\
\text { extension } \\
\text { services } \\
\text { The need to } \\
\text { improve } \\
\text { quality } \\
\text { The motive for } \\
\text { high prices } \\
\text { Demand for } \\
\text { value-added } \\
\text { products }\end{array}$ & $\begin{array}{l}\text { - Increased assembling } \\
\text { cost } \\
\text { - } \quad \text { Corruption } \\
\text { - The sophistication of } \\
\text { market channels } \\
\text { - Loss of trust } \\
\text { - Increased extension } \\
\text { services Digital } \\
\text { marketing } \\
\text { - Increased awareness of } \\
\text { the perceived health } \\
\text { benefits of vegetables } \\
\text { - Increased health } \\
\text { problems } \\
\text { - Increased nutritional } \\
\text { awareness }\end{array}$ \\
\hline
\end{tabular}

Source: Focus Group Data (2019)

There were poor roads to the market places hence difficulties in distributing vegetables and this could lead to deterioration in value. There were challenges in packaging of the vegetables during transportation and this led to loss of nutrients. This finding is in line with Chianu et al. (2008) who showed that about $62 \%$ of the producers used bicycles as the main means of transporting agricultural produce to the market places.

During this phase, there was low demand for vegetables in the markets. This is because almost all households produced vegetables for their own consumption. There was low market for vegetable and vegetable products due to communalism where people could borrow vegetables from their neighbors without necessarily paying for them. There was low adoption of formal contracts hence spot markets could work for the farmers. Huge quantities of vegetables could be sold at low prices due to high production. There were high levels of trust hence verbal/informal contracts were used during marketing of vegetables and these contracts were not binding although they used to work due to social norms and values.

For assembling practices, there were cooperatives responsible for assembling farmers' vegetable at the beginning of marketing activities. Farmers were however complaining about exploitation by the cooperative officials when it came to dealing with farmer's vegetables. The cooperatives were strengthened with the help of the national and local governments. Farmers faced the challenge of poor assembling facilities hence losses were incurred all along.

In vegetable consumption, ease of cooking was not of concern for the consumers of vegetables. Household could take long to prepare vegetables, which in turn could be served over several days. Traditional varieties like spider plant were most preferred and available. There was low demand in the market since every household could produce vegetables for consumption. Every household could consume what is produced on farm and sometimes borrow from the neighbors. Most of the vegetables produced and consumed were traditional vegetables like black nightshade and cowpeas. This is in line 
with Ngugi et al. (2007) who found that households especially women highly depend on vegetables for nutrition and health for development.

Between the year 1991 and 2000, vegetable farmers were using farmyard manure prepared on the farm to produce vegetables. Kitchen wastes and animal wastes were allowed to decompose and then disintegrated into medium sized granules and spread across the piece of land where the vegetables were to be grown. Wainaina et al. (2016) also found that the farmers were using organic manure in this period due to its abundance and lower cost of acquisition. Seeds were prepared traditionally where they were acquired from the farm and some farmers could borrow from the neighbors. There was the emergence of improved seed varieties from about 1995. Farmers started adopting new scientific improved varieties, which they still mixed with the traditional seeds. Farmers also started combining organic and chemical fertilizers.

Production of AIVs was mainly carried out for subsistence. The farmers could ensure timely production so as to meet the household vegetable requirements. Production was continuous since the weather patterns could allow for several cropping within a year. The farmers still employed traditional production methods such as broadcasting. Farmers feared accessing credit due to the need of collateral hence farming credit was not common. Extension services from the ministry of agriculture were rare as well. However, there were high yields recorded in vegetables due to high soil fertility. A decline in the number of animals led to a shortage of manure hence, decline in production. Credit access was not easy still due to tedious procedures involved and the fear of the consequences of unpaid loans. Fischer and Qaim (2012) asserted that the low access to credit services was due the need for collateral by formal lending institutions. This required farmers to be in groups so as to pool resources to use as collateral for credit.

There were low incidences of pests and diseases and adequate water for vegetable productions. The nutrition importance of traditional vegetable was the motivation for improved production of vegetables. Mixed cropping was also practiced. There was an increasing number of farmer-led extension services for instance, farmers' field schools (FFS) emerged, where a lead farmer could teach the other farmers production of vegetables in terms of technical knowledge. These findings corresponds to Quisumbing and Pandolfelli (2010) who noted that the increasing extension services among smallholder producers increases chances of market linkages. It was found that, both men and women participated in distribution of vegetables with women using their heads to carry vegetables while men used bicycles to distribute vegetables from village to village. There was poor infrastructure, roads included and this posed challenges in vegetable distribution. Post-harvest losses continued to be experienced among vegetable producers due to inadequate distribution facilities.

Climate change became more evident in this period. This reduced production and hence supply of vegetables in the market. This in turn raised market prices for vegetables and induced high demand due to undersupply. Brokers emerged and started participating in marketing of vegetables. The respondents had a conflicted perception of the role of brokers in vegetable marketing where $27 \%$ of the respondents perceived brokers to be of great importance in helping farmers to price their vegetables while $60 \%$ perceived brokers as agents who exploit farmers by picking their vegetables at lower prices and selling to the final consumer at higher prices making more profits as compared to farmers. The markets were unpredictable due to low adoption of formal contract farming. Those few farmers who practiced contract farming earned higher than those who were not in contract farming. Farmers supplying to schools, hotels and hospitals on contracts enjoyed benefits of predictable and reliable markets. The emergence of supermarkets benefited those farmers who supplied through tenders by offering consistency and higher prices than other channels. These results correspond to those by Bellemare and Novak (2017) who showed that contract farming has a positive impact on the smallholder farmers by enabling them to gain better access to high value-local and global markets.

The assembling activities were still low except for large market places that had order and structures for assembling. There was still inadequate infrastructure at the market places to allow for assembling of vegetables. Farmers with large quantities could however decide to pool resources and assemble their produce at one point where they could be picked and transported to the market. This was rare though due 
to mistrust issues. In this phase, value addition was left for companies and private organizations. Very few individuals engaged in value addition of vegetables since there was fear of additional costs in terms of time, skills and resources required in value addition, while overlooking the accruing benefits. The national government intervened in the situation by promoting value addition among producers. The government through the ministry of agriculture's extension officers offered trainings to farmers on value addition practices and its benefits on income and profits. Among the activities done to add value to vegetables included cleaning, chopping, drying, grinding into powder, baking cakes and juice extraction. These findings relate to Bostrom et al. (2016) observations that attribute the low participation in value addition practices to market failures due to high transaction costs and lack of networks

There was an increased awareness of the nutritional value of traditional vegetables hence increased demand and consumption of the same as compared to exotic varieties. The consumption patterns changed due to spread of knowledge about the medicinal and nutritional value of traditional vegetables. Between the year 2001 and 2010, there was the spread of chemical fertilizers and use of improved seed varieties for vegetables. There was also the emergence of agro-vets to supply vegetable farmers with inputs (seeds, fertilizers and agrochemicals). Application of inputs like fertilizer-improved production as stated by Sombié, Sama, Sidibé and Kiendrébéogo (2019). In this period, there was a spread in the use of improved varieties of vegetable, with farmers embracing both exotic and traditional varieties of vegetables. Wainaina et al. (2016) also found that there has been a decline in the use of organic fertilizers in this period as compared to 1980s. This is because organic manure was cheap, readily available and environmentally friendly hence mostly used then and now it is scarce due to reduced herds of animals, costly and adulterated hence not environmentally sustainable.

There was an increase in awareness of the ministry of agriculture's extension officers. These could work alongside farmer-led extension services. There were challenges in terms of corruption among government service providers. Labor started becoming expensive, hence increasing the cost of production. Farmers started facing credit challenges since there were very few microfinance providers and those present had restrictions in providing credit. The use of traditional farming methods begun to fade away and vegetable farmers started embracing line planting beginning from 2005. Vegetable production took a turn from subsistence production to more of commercial production where farmers produced for market. The ministry of agriculture at county level started deploying more extension officers to offer training and technical knowledge to vegetable farmers.

During this period, there was the emergence of motorcycles, which were faster and effective hence reducing transportation time to the markets. This helped to reduce losses that occurred due to delays during distribution. The challenges involved included low value addition and long distances to the market places. There was an increase in the number of motorcycles transporting vegetables to market places, schools, hospitals, hotels and other buying points. Animal-drawn implements could be used to carry vegetables as well by interior farmers to reach the nearest selling points. Distribution of vegetables could be done in groups in order to cut down on costs. In order to reduce waste during distribution, the government started encouraging farmers to do value addition. Value addition also helped farmers to maximize profits.

Vegetable producers started practicing group marketing to cut down on marketing costs. There was spread of supermarkets, which required producers to supply vegetables on contract. Most farmers could sell on roadsides, in towns and village markets. Vegetable farmers still faced poor storage facilities at market places hence losses were inevitable. During rainy reasons, production was high, hence oversupply leading to losses for farmers without forward markets. The prices of vegetables begun to increase due to climate change that led to shortages in supply. The supermarkets continued to increase and there was pressure on quality standards of vegetables required in the market. These observations are related to Ngenoh et al. (2019) who found that access to information and technology increases participation of farmers in high value chain markets.

Assembling of vegetables became more common due to increase in the number of brokers. There was need to establish assembling points in order to harness markets and perform group marketing. However, there was less transparency in the assembly dealings. The introduction of the free-market system led to 
increased corruption that created inefficiencies in assembling activities. Value addition practices begun to spread among vegetable producers. The development of storage facilities helped to add value to vegetables by increasing place and time utility. The improvement of infrastructure, transport system and electricity included helped to enhance value addition in vegetables

Consumers' tastes and preferences were inclined towards the health benefits of the vegetables they were consuming. The traditional vegetables became the order of the day and this increased the prices of traditional vegetables but still people could buy due to the perceived importance. The youth preferred exotic varieties while the elderly preferred the traditional varieties. The young individuals preferred exotic vegetables like kales due to ease of cooking. The young people lacked knowledge on the preparation of the traditional vegetables.

In the year 2011 to 2019, more stakeholders in agriculture including research institutions, buyers and private organizations continued to provide inputs to farmers mostly on credit or in kind. There has been an increase in the use of chemical fertilizers although there are health concerns as far as chemical residues in vegetables are concerned. There has been a campaign for organic farming to control for chemical contaminations in vegetables. Improved seed varieties for both traditional and exotic varieties are being encouraged to improve productivity and general vegetable production. This is consistent with Kansiime et al. (2018) who observed that there is lack of knowledge about the demand for vegetable seeds especially indigenous. This makes it difficult to promote large-scale production of these seeds to meet the high demand.

It was revealed that, farmers started embracing technologies like kitchen gardens, which are easy to manage especially for household vegetable production. Despite changes in planting times, due to unpredictable weather, vegetable farmers embraced coping strategies like conservation farming and irrigation to ensure yield and income. Quisumbing and Pandolfelli (2010) made a similar observation that practices that maintain soil fertility like conservation agriculture increases yields and access to markets.

There has been an increased use of motorcycles and vehicles in distributing vegetables. Some farmers still use bicycles for shorter distances. There has been a campaign for value addition to help reduce distribution losses given that value added vegetable products can stay for long as compared to fresh vegetables. Value addition practices include packaging, drying, juice making and cake baking. There is high cost of accessing vehicles with special facilities for preserving vegetables in transit especially for long distances.

Markets for vegetables have increased over time. Many people demand vegetable and vegetable products. The prices have increasingly become higher. Contracts have become more popular and their perceived benefits are high in terms of income and reliability. There has been low trust in informal agreements hence the justification for rising formal contracts. Farmers face challenges in meeting the required standards in the markets. The storage facilities are still not meeting standards despite improvements by the county governments. The vegetables are marketed locally and in foreign markets. These findings are similar to those of Ngenoh et al. (2019) who showed that the demand for indigenous vegetables was on the rise. The introduction of supermarkets in early 2000 provided an avenue for farmers to supply vegetables on contracts.

It was also revealed that assembling activities have come along with the creation of employment opportunities for youths who are actively involved in the value chain. Assembling enhances efficiency in marketing vegetables and also helps to reduce transaction costs for farmers especially when done in groups. Digital markets have become very popular and proved to be effective in the allocation of goods, vegetables included. There have been improved security measures during assembling even if insurance is yet to be fully actualized. Issuance of receipts in the market stalls helps in protecting the farmers' vegetables from loss or theft. Political instability in 2015 led to immigration and this increased demand for vegetables within the county. There has been an improvement in value addition of vegetables. The incentive for increased value addition activities includes attracting high prices, improving keeping quality and profits in general. Value addition practices include baked products from traditional vegetables, vegetable powder, juice, dried vegetables, and improvised packaging. It was revealed that $40 \%$ of the respondents did not practice value addition. The farmers' perception of and participation in value addition 
was varied with one-quarter of them equally distributed in these categories: those who considered it to be time-consuming and therefore did not participate at all; the skeptics of any potential benefits; those who lacked insights of how to add value and the final category that were contended with only producing the vegetables'.

For consumption, consumers go for fast-cooking foods. Ease of cooking is of great concern to consumers unlike in 1980 due to declining levels of patience. Some consumers prefer vegetables produced organically without chemicals. The chemical residue is a matter of public debate as far as human health is concerned. The vegetables from the county are consumed locally and traditionally.

\section{Evolution of Contracts and the Key Drivers}

As seen in table 2, it was revealed that from 1980 to 1990, there were informal contracts that involved oral agreements with relatives and friends to provide labor, inputs, buy and sell vegetables. The contract's duration was from a week to several years and the contract terms were being observed. There were a few cases of violation due to strong level of trust. In case of violation, the party that violated could be fined by the community. Household heads and village elders resolved disputes.

From 1991 to 2000, the informal contracts begun to lose trust and violation became a great challenge. This necessitated the need for formal contracts, which were written and binding with sanctions involved. Village elders, chiefs and parties involved could solve disputes in case of any. The buyers used to set price and the sellers were price takers. In the agreement, the quality, quantity and time of delivery were agreed upon and the parties had to observe the agreement. The mode of payment was cash on delivery but sometimes the buyers could provide inputs to sellers upfront, on credit then deduct from the sellers income at the end of the growing season.

Between 2001 and 2010, the contracts were both formal and informal. Formal contracts had written agreements while informal had oral agreements. Oral agreements could be applied in ploughing, weeding, distribution and production activities. Written agreements applied to selling and buying of the vegetables, but trust continued to deteriorate. Buyers could at times supply inputs to the sellers/producers in advance then the cost deducted from their ultimate pay. From 2011 to 2019, the contracts were both formal and informal. Mode of payments could range from installments to cash on delivery. The agreement-involved time of delivery, time of payment, the price offer, the quantity, the value addition practice, the quality and transportation logistics. The formal contracts such as supplying to schools were found to be effective and reliable. Farmers could be sure of stable income. Violation of contracts by either party remained a problem in some cases. Informal contracts applied in distribution of vegetables. Formal contracts with written agreements became very common. 
TABLE 2

EVOLUTION OF CONTRACTS AND KEY DRIVERS FROM 1980-2019

\begin{tabular}{|c|c|c|c|c|}
\hline & $1980-1990$ & $1991-2000$ & $2001-2010$ & $2011-2019$ \\
\hline 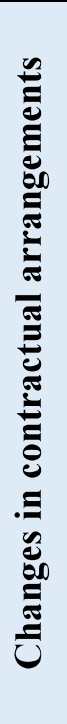 & $\begin{array}{l}\text { - } \text { Informal } \\
\text { contracts } \\
\text { - } \text { Oral agreements } \\
\text { - } \text { Disputes } \\
\text { resolved by } \\
\text { village elders } \\
\text { - } \text { Communal } \\
\text { agreements } \\
\text { - No court } \\
\text { sanctions }\end{array}$ & $\begin{array}{l}\text { Decreased } \\
\text { duration from } \\
\text { years to } \\
\text { months } \\
\text { - Flexibility in } \\
\text { contract } \\
\text { duration }\end{array}$ & $\begin{array}{l}\text { A move from } \\
\text { communal } \\
\text { agreements } \\
\text { Introduction } \\
\text { of legal } \\
\text { sanctions } \\
\text { - Combination } \\
\text { of oral and } \\
\text { written } \\
\text { agreements } \\
\text { Increased } \\
\text { focus on high } \\
\text { standards of } \\
\text { produce }\end{array}$ & $\begin{array}{l}\text { - } \begin{array}{l}\text { Buyers determine the } \\
\text { price }\end{array} \\
\text { - Involvement of producers } \\
\text { in price setting } \\
\text { - Flexibility in price } \\
\text { - Formal contracts } \\
\text { - Upfront input supply by } \\
\text { buyers } \\
\text { Contracting firms offer } \\
\text { credit services } \\
\text { Pricing in relation to } \\
\text { standards } \\
\text { - Increased farmers' } \\
\text { violation } \\
\text { Increased buyers' } \\
\text { violation }\end{array}$ \\
\hline 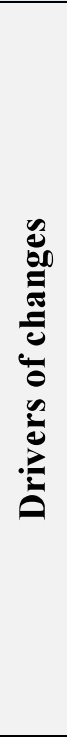 & 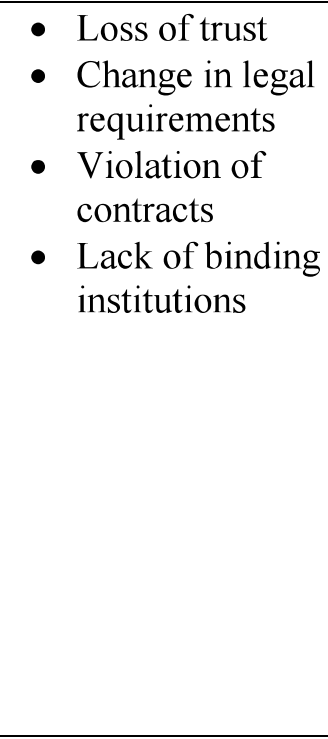 & $\begin{array}{ll}\text { - } & \begin{array}{l}\text { Change in } \\
\text { production }\end{array} \\
\text { seasons } \\
\text { - } & \text { Instability in } \\
\text { supply } & \text { Market } \\
\text { - } & \text { demand } \\
\text { - } & \text { Change of } \\
\text { production } \\
\text { seasons } \\
\text { - } \begin{array}{l}\text { Market } \\
\text { demand }\end{array}\end{array}$ & $\begin{array}{ll}\text { Increased } \\
\text { violation of } \\
\text { contracts } \\
\text { - } \\
\text { Declined } \\
\text { influence of } \\
\text { village elders } \\
\text { in dispute } \\
\text { resolution } \\
\text { - Market } \\
\text { demand } \\
\text { Expansion to } \\
\text { foreign } \\
\text { markets strict } \\
\text { on quality }\end{array}$ & 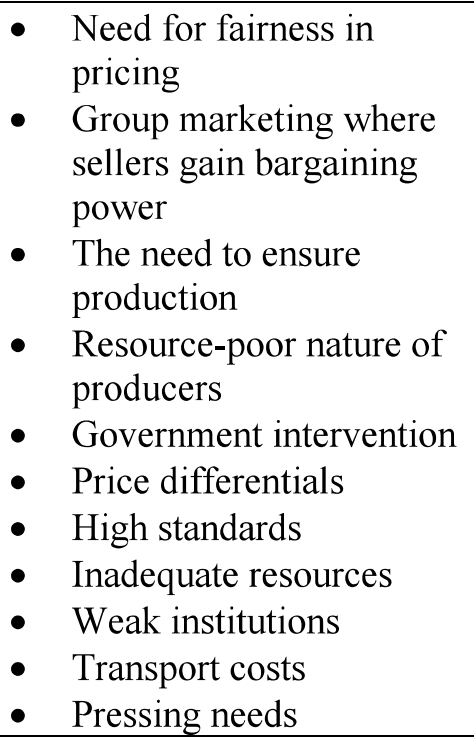 \\
\hline
\end{tabular}

Source: Focus Group Data (2019)

\section{Violation of Contracts}

It was noted from the focus group discussion that the major factors leading to farmers violating contracts are: price differentials, where contracting firms or buyers offer prices that are lower than the prevailing market prices; transport cost, where the farmer is required to deliver the produce to the buyer at additional costs and; pressing needs of the farmers such as school fees that make them side sell to meet the current needs, which require urgent attention. In addition, delay of the buyers to pay farmers causes farmers to violate the subsequent agreements. Sometimes buyers become dishonest in their dealings for instance use of faulty scales to give wrong measurements to exploit the farmers. The mode of payment also contributes to the violation of contracts whereby farmers will tend to prefer full payment rather than installments offered by contracting firms or buyers. Mugwagwa (2019) also observed the disincentives of contract parties lead to violation of contracts hence they should be considered in designing arrangements. 
The price differential is contrary to Larre (2019) hypothesis that price of equal goods tend to equalize in open markets.

Due to lack of written agreements, farmers are not obliged in any way since oral contracts are not binding. There has also been emergence of buyers who exploit farmers whereby, they bear fake credentials and once they get the farmers vegetables, they disappear without paying and they cannot be traced thereafter. Sometimes farmers expect to acquire resources and technical expertise to produce and meet the required standards in the contract hence the violation of contracts. These findings are similar to Singh (2002) where it was found that smallholder farmers violate contracts in cases where buyers (firms) portray unfavorable behavior for instance, when buyers: provide poor extension services, offer low prices for produce, overprice their services, pass their risks to producers and delay in payments for produce. Figure 1 below shows the perceptions of vegetable farmers on factors leading to violation of contracts.

\section{FIGURE 1 \\ FACTORS LEADING TO VIOLATION OF CONTRACTS}

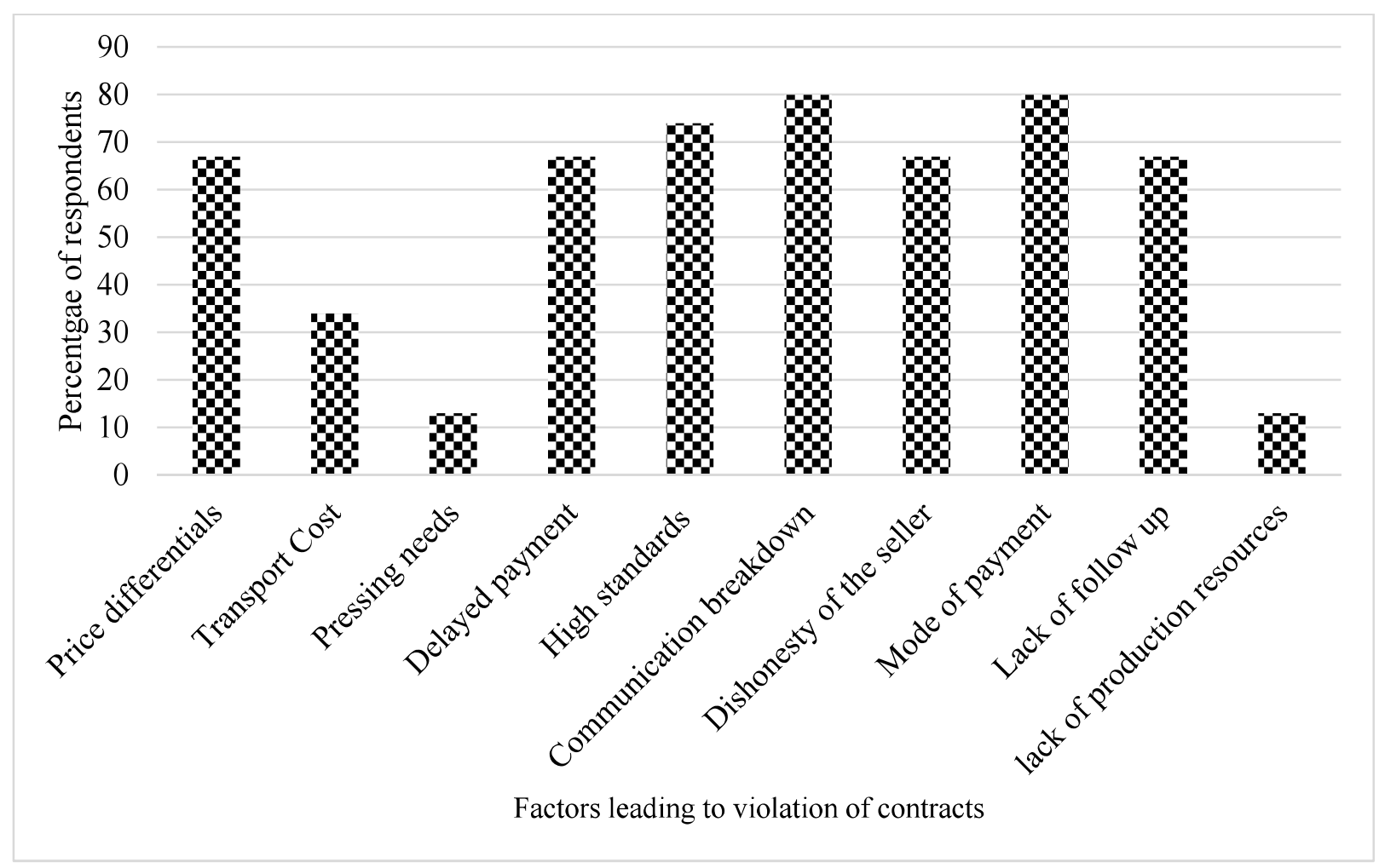

Source: Focus Group Data (2019)

\section{Effects of Contracts on Livelihoods}

Similar to the observations of Bellemare and Novak (2017), it was noted that contract farming has a positive effect on the smallholder farmers by enabling them to gain better access to markets and hence gain better incomes due to stability in demand and assurance of the market. Consistent supply of good quality inputs by the contracting firms also increases the vegetable yields. The results are also similar to Fischer and Qaim (2012) and Rao et al. (2012) who found that linking farmers to markets reduces production cost and improves the economic linkages.

Farmers who participate in contract farming are more nutritionally secure than non-participants are. Contract farmers gain extra income to purchase food that they do not produce. These findings are in line with Bellemare (2015), who found that households who participate in contract farming get additional income that they use to purchase more food especially the period before the next harvest thus making 
them food secure. Ngenoh et al. (2016) also mention that smallholder farmers participating in integrated marketing of vegetables have a strong livelihood potential. Figure 2 below shows the benefits accruing from contract farming and how farmers' livelihoods are affected.

\section{FIGURE 2 \\ EFFECTS OF CONTRACT FARMING ON LIVELIHOODS}

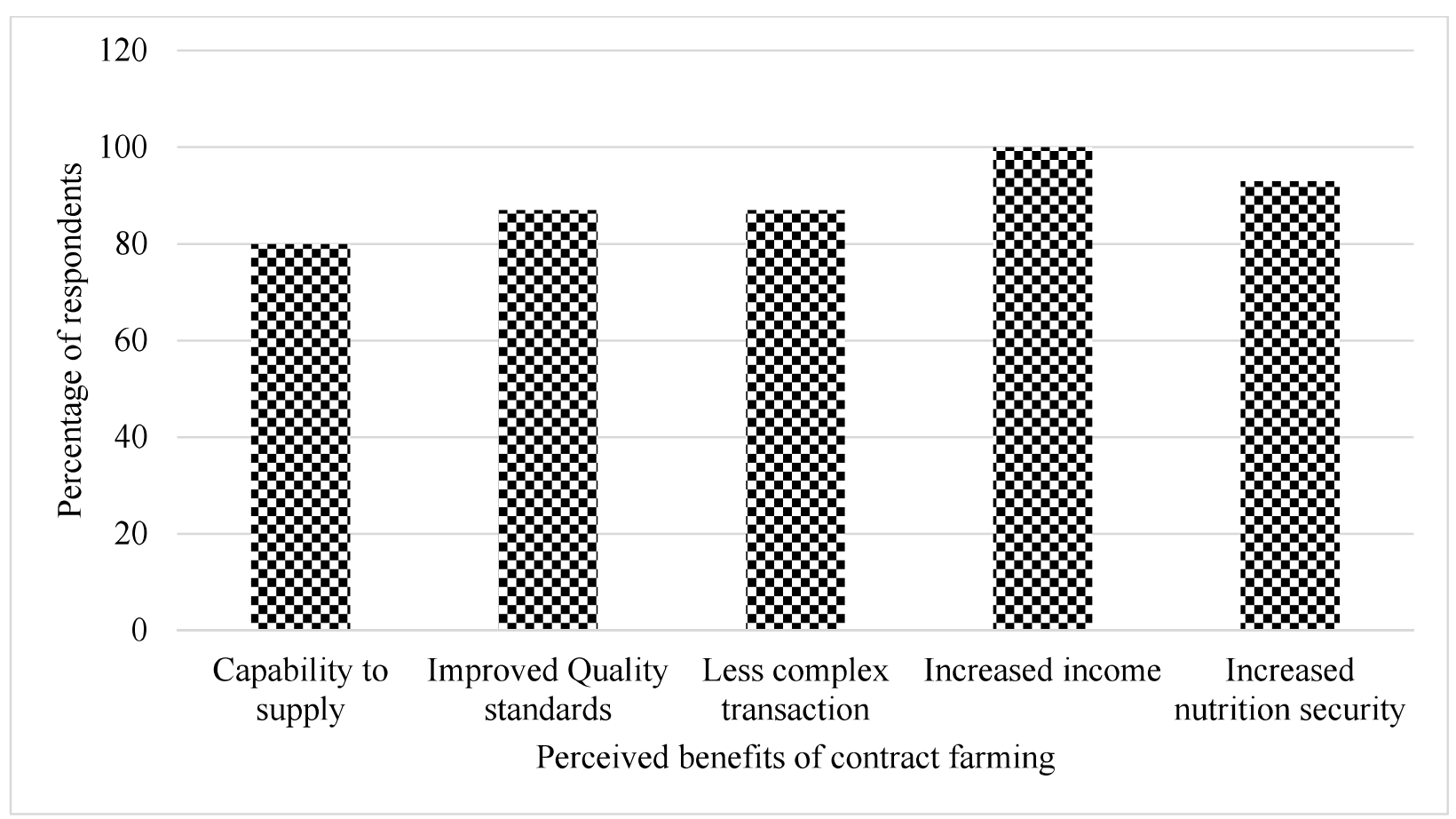

Source: Focus Group Data (2019)

\section{CONCLUSIONS AND POLICY IMPLICATIONS}

This study analyzed the drivers of transformations in smallholder indigenous vegetable value chains and contract farming evolution. The results indicate that there has been a shift from traditional to modern farming of vegetables. Compared to the early years of use of homemade inputs, vegetable producers have embraced improved seed varieties, and increased use of inorganic fertilizers. Distribution of vegetables has evolved where better facilities are being introduced for instance well-designed vehicles. Supermarkets have emerged and farmers are finding their way to supply on contracts. Value addition is becoming popular where smallholder farmers are increasingly striving to play an important role in serving the emerging needs for convenient foods by the growing peri-urban consumer segments. The contract being one of the innovative marketing models has undergone several changes. Formal contracts characterized by written agreements are becoming increasingly popular among the farming communities. It was revealed that contract farming has a positive influence on the livelihoods of vegetable producers in terms of increased incomes and nutrition security.

It is important to enable farmers to clearly understand the terms and conditions of the contract before they sign it. This could be achieved by the introduction of an independent third party to ensure farmers understand what they sign for hence fairness. Farmers should adopt improved seed varieties to increase productivity. Vegetable farmers should invest more in value addition to increase their profitability and livelihoods. Sub-Saharan governments, non-governmental organizations and other stakeholders should increase their training frequencies to farmers concerning value addition practices and the associated benefit to increase livelihoods. Moreover, the governments should strengthen cooperatives by 
encouraging use of technology in tracking farmers' produce to enhance transparency. Strict penalties for fraud and misconduct should be imposed on cooperatives and individuals who engage in such practices that create inefficiencies in marketing of vegetables.

In order to enhance the productivity of farmers, governments should increase the number of officers providing extension services. The contracting firms should increase the frequency of visits to the farmers so as to ensure good agricultural practices are followed for improve productivity and maintenance of market standards. Extension service providers including government, non-governmental organizations and contracting firms should incorporate information computer technology in extension services for instance, development of extension services apps and use of text messages to dissemination information to farmers at lower costs. Further, governments should preserve water catchment areas to cope with the changing climate. Governments should improve infrastructure ranging from roads, electricity and market facilities to augment vegetable trade. Strengthening of standards in input supply is key to realize significant yields.

The national governments should increase efficiency in the dissemination of the weather forecasting information to farmers for early preparations. Governments should increase research and development to enhance the productivity of vegetable farmers. The government should cut down on the cost of inputs. Microfinance institutions should reduce the interest on agricultural loans to encourage uptake of loans. Farmers should be involved in price determination especially in contractual agreements. In contract farming, bias should be eliminated whereby sanctions should be applied to all the involved parties and not just the seller, in case of breach of contracts. Finally, the government and regulatory bodies should put into account the incentives and disincentives of contracting firms when designing programmes and policies of promoting contract farming to ensure that there is a balance in benefits between the contracting and contracted parties.

\section{ACKNOWLEDGEMENTS}

The authors are grateful to African Economic Research Consortium (AERC) for funding the study.

\section{REFERENCES}

Afari-Sefa, V., Rajendran, S., Kessy, R., Karanja, D., Musebe, R., Samali, S., \& Makaranga, M. (2016). Impact of nutritional perceptions of traditional African vegetables on farm household production decisions: A case study of smallholders in Tanzania. Experimental Agriculture, 52(2), 300-313. https://doi.org/10.1017/S0014479715000101

Bellemare, M., \& Novak, L. (2017). Contract farming and food security. American Journal Agricultural Economics, 99(2), 357-378. https://doi.org/10.1093/ajae/aaw053

Bellemare, M. (2012). As you sow, so shall you reap. The welfare impacts of contract farming. World Development, 40(7), 1418-1434. https://doi.org/10.1016/j.worlddev.2011.12.008

Boström, M., Jönsson, A., Lockie, S., Mol, A., \& Oosterveer, P. (2015). Sustainable and responsible supply chain governance: Challenges and opportunities. Journal of Cleaner Production, 107(1), 1-7. https://doi.org/10.1016/j.jclepro.2014.11.050

Byerlee, D., de Janvry, A., \& Sadoulet, E. (2009). Agriculture for Development: Toward a New Paradigm. Annual Review of Resource Economics, 1(1), 15-31. https://doi.org/10.1146/annurev.resource.050708.144239

Chianu, J., Ajani, N., \& Chinua, N. (2008). Livelihoods and rural wealth distribution among farm households in Western Kenya: Implications of rural development, poverty alleviation interventions and peace. African Journal of Agricultural Research, 3(7), 455-464. Retrieved from http://www.academicjournals.org/AJAR

Da Silva, C., \& Ranking, M. (2013). Contract farming for inclusive market access. Rome. Food and Agriculture Organization of the United Nations (FAO). 
Fischer, E., \& Qaim, M. (2012). Linking smallholders to markets: Determinants and impacts of farmer collective action in Kenya. World Development, 40(6), 1255-1268. https://doi.org/10.1016/j.worlddev.2011.11.018

Jalang'o, D., Otieno, D., \& Oluoch-Kosura, W. (2018). Commercialization of African Indigenous Vegetables in Kenya. In E. Muluken \& B. Wolfgang (Eds.), Value Chain Development for Food Security in the Context of Climate Change: Perspectives and Lessons from a North-South Capacity Building Project (chapter three, pp. 36-45). Berlin: Verlag Dr. Koster.

Kansiime, M., Nicodemus, J., Kessy, R., Afari-Sefa, V., Marandu, D., Samali, S., . . \& Karanja, D. (2016). Good Seed for Quality Produce: Indigenous Vegetables Boost Farmer Incomes and Livelihoods in Tanzania. CABI Impact Case Study 17. Nairobi: CABI. Retrieved from https://www.cabi.org/Uploads/CABI/long-case-studies/Case\%20study\%2017.pdf

Kansiime, M., \& Mastenbroek, A. (2016). Enhancing resilience of farmer seed system to climate-induced stresses: Insights from a case study in West Nile region, Uganda. Journal of Rural Studies, 47(1), 220-230. https://doi.org/10.1016/j.jrurstud.2016.08.004

Kansiime, M., Karanja, D., Alokit, C., \& Ochieng, J. (2018). Derived demand for African indigenous vegetable seed: Implications for farmer-seed entrepreneurship development. International Food and Agribusiness Management Review, 21(6), 723-739. https://doi.org/10.22434/IFAMR2017.0095

Larre, G. (2019). Market Integration in the International Market of Soybeans: Are GM Soy and Non-GM Soy Markets Integrated? Journal of Agricultural Science, 11(15), 14. https://Doi.10.5539/jas.v11n15p14

Milena, Z., Dainora, G., \& Alin, S. (2008). Qualitative research methods: A comparison between focusgroup and in-depth interview. Annals of the University of Oradea, Economic Science Series, 17(4), 1279-1283. Retrieved from https://econpapers.repec.org/scripts/redir.pf?u=http $\% 3 \mathrm{~A} \% 2 \mathrm{~F} \% 2 \mathrm{Fsteconomice}$.uoradea.ro\%2Fana le\%2Fvolume $\% 2$ F2008\%2Fv4-managementmarketing\%2F235.pdf;h=repec:ora:journl:v:4:y:2008:i:1:p:1279-1283

Mugwagwa, I., Bijman, J., \& Trienekens, J. (2019). Why do agribusiness firms simultaneously source from different contract farming arrangements? Evidence from the soybean industry in Malawi. International Food and Agribusiness Management Review, 22(1), 79-96. https://doi.org/10.22434/IFAMR2018.0079

Muhanji, G., Roothaert, R., Webo, C., \& Stanley, M. (2011). African indigenous vegetable enterprises and market access for small-scale farmers in East Africa. International Journal of Agricultural Sustainability, 9(1), 194-202. https://doi.org/10.3763/ijas.2010.0561

Ngeno, E., Kurgat, B., Bett, H., Kebede, S., \& Bokelmann, W. (2019). Determinants of the competitiveness of smallholder African indigenous vegetable farmers in high-value agro-food chains in Kenya: A multivariate probit regression analysis. Agricultural and Food Economics, 7(1), 2-8. https://doi.org/10.1186/s40100-019-0122-z

Ngenoh, E., Kebede, S., Bett, H., \& Bokelmann, W. (2016). Role of high-valued market participation on poverty reduction among African leafy vegetable farmers in Kenya. African Journal of Horticultural Science, 10(1), 14-20. https://www.researchgate.net/publication/282087676

Ngugi, I., Gitau, R., \& Nyoro, J. (2007). Access to high value markets by smallholder farmers of African indigenous vegetables in Kenya. Regoverning Markets Innovative Practice Series, IIED, London.

Ochieng, J., Afari-Sefa, V., Karanja, D., Kessy, R., Rajendran, S., \& Samali, S. (2018). How promoting consumption of traditional African vegetables affects household nutrition security in Tanzania. Renewable Agriculture and Food Systems, 33(2), 105-115. https://doi.org/10.1017/S1742170516000508

Oya, C. (2011). Contract Farming in Sub-Saharan Africa: A Survey of Approaches, Debates and Issues. Journal of Agrarian Change, 12(1), 1-33. https://doi.org/10.1111/j.1471-0366.2011.00337.x

Prowse, M. (2012). Contract Farming in Developing Countries - A review. Hilaire-le-Châtel, Imprimerie de Montigeon. Retrieved from https://www.researchgate.net/publication/321224983

164 Journal of Applied Business and Economics Vol. 22(6) 2020 
Quisumbing, A., \& Pandolfelli, L. (2010). Promising approaches to address the needs of poor female farmers: Resources, constraints, and interventions. World Development, 38(4), 581-592. https://doi.org/10.1016/j.worlddev.2009.10.006

Rao, E., Brümmer, B., \& Qaim, M. (2012). Farmer participation in supermarket channels, production technology and efficiency: The case of vegetables in Kenya. American Journal of Agricultural Economics, 94(4), 891-912. https://doi.org/10.1093/ajae/aas024

Republic of Kenya. (2016). Validated Report, Agriculture and Food Authority Horticultural Crops Directorate. Nairobi, Kenya National Bureau of Statistics.

Republic of Kenya. (2019). Gross County Product. Report. Nairobi, Kenya National Bureau of Statistics. Singh, S. (2002). Contracting Out Solutions: Political Economy of Contract Farming in the Indian Punjab. World Development, 30(9), 1621-1638. https://doi.org/10.1016/S0305-750X(02)00059-1

Sokchea, A., \& Culas, R. (2015). Impact of contract farming with farmer organizations on farmers' income: A case study of Reasmey Stung Sen agricultural development cooperative in Cambodia. Australasian Agribusiness Review, 23(1), 42-49.

Sombié, P., Sama, H., Sidibé, H., \& Kiendrébéogo, M. (2019). Effect of Organic (Jatropha Cake) and NPK Fertilizers on Improving Biochemical Components and Antioxidant Properties of Five Cowpea (Vigna unguiculata L. Walp.) Genotypes. Journal of Agricultural Science, 11(10), 48. https://Dio.10.5539/jas.v11n10p48

Ton, G., Vellema, W., Desiere, S., Weituschat, S., \& D'Haese, M. (2018). Contract farming for improving smallholder incomes: What can we learn from effectiveness studies? World Development, 1(104), 46-64. https://doi.org/10.1016/j.worlddev.2017.11.015

Wainaina, P., Tongruksawattana, S., \& Qaim, M. (2016). Tradeoffs and complementarities in the adoption of improved seeds, fertilizer, and natural resource management technologies in Kenya. Agricultural Economics, 47(3), 351-362. https://doi.org/10.1111/agec.12235

Weinberger, K., \& Lumpkin, T. (2007). Diversification into Horticulture and Poverty Reduction: A Research Agenda. World Development, 35(1), 1464-1480. https://doi.org/10.1016/j.worlddev.2007.05.002

World Bank. (2008). World Development Report 2008: Agriculture for development. Washington D.C. World Bank. 